\title{
Expedition 308 synthesis: overpressure, consolidation, and slope stability on the continental slope of the Gulf of Mexico'
}

\author{
P.B. Flemings, ${ }^{2}$ C. John, ${ }^{3}$ and J. Behrmann ${ }^{4}$
}

\section{Chapter contents}

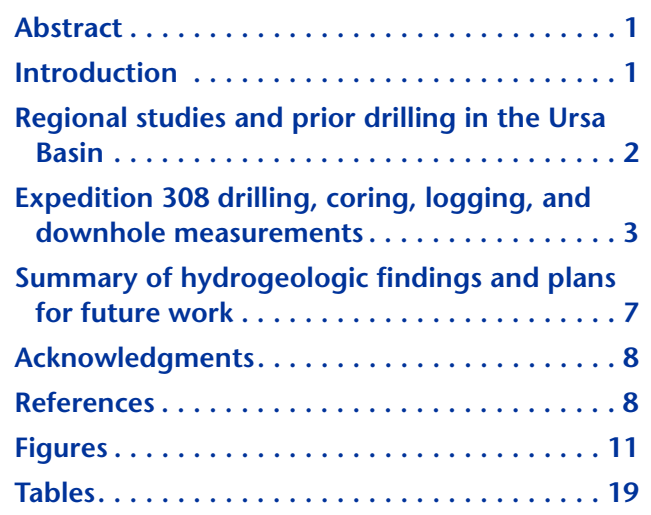

1Flemings, P.B., John, C., and Behrmann, J., 2012. Expedition 308 synthesis: overpressure, consolidation, and slope stability on the continental slope of the Gulf of Mexico. In Flemings, P.B., Behrmann, J.H., John, C.M., and the Expedition 308 Scientists, Proc. IODP, 308: College Station TX (Integrated Ocean Drilling Program Management International, Inc.). doi:10.2204/iodp.proc.308.215.2012 ${ }^{2}$ Department of Geological Sciences, The University of Texas at Austin, 1 University Station, Austin TX 78712, USA. pflemings@jsg.utexas.edu ${ }_{3}^{3}$ Petroleum Geoscience and Earth Science, Imperial College London, London SW7 2AZ, United Kingdom.

${ }^{4}$ Leibiniz-Institut für Meereswissenschaften, IFMGEOMAR, Gebäude Ostufer, Wischhofstrasse 1-3, 24148 Kiel, Germany.

\section{Abstract}

Integrated Ocean Drilling Program Expedition 308 quantified the coupling between sedimentation, consolidation, overpressure, fluid flow, and slope instability in continental margin settings. We summarize and synthesize peer-reviewed hydrogeologic studies published since the end of Expedition 308 that focus on Expedition 308 sites drilled in Ursa Basin: Sites U1322, U1323, and U1324. There is a rich stratigraphic complexity in the Ursa Basin, deepwater Gulf of Mexico. The sandstone-prone Blue Unit is a permeable aquifer overlain by mudstone-prone leveed-channel deposition. Multiple mass transport deposits, each densified relative to surrounding material, are present. Eight coeval surfaces mapped across the drilling transect span $\sim 70$ ka to present. Sedimentation rates were $>10 \mathrm{~mm} / \mathrm{y}$ at Site U1324. In situ penetrometer measurements document severe overpressures that begin at or near the seafloor and extend to the base of the drilled holes. Uniaxial consolidation experiments quantified the compression behavior of the sediments and provided an approach to predict pressure from porosity. Laboratory analysis of permeability and compressibility document that the coefficient of consolidation (hydraulic diffusivity) of Ursa Basin mudstones is $10^{-8} \mathrm{~m}^{2} / \mathrm{s}$ over the effective stresses encountered during drilling at Ursa Basin ( 0.1 to $5 \mathrm{MPa})$. This low and constant value for the coefficient of consolidation is responsible for the presence of high overpressure very near the seafloor. Although permeability is very high, the sediments are also highly compressible. Forward modeling of Ursa Basin sediments shows that overpressure near the seafloor is reasonable given the rock properties and sedimentation rates that are observed. Modeling also illustrates that flow is driven laterally along an underlying aquifer, the Blue Unit. Soon after Blue Unit deposition, lateral flow induced submarine landslides. Later in the evolution of this system, overpressure may have preconditioned the slope to failure by earthquakes of magnitude 5.0.

\section{Introduction}

Integrated Ocean Drilling Program (IODP) Expedition 308 was dedicated to the study of shallow overpressure, flow focusing, and slope stability (see the "Expedition 308 summary" chapter [Expedition 308 Scientists, 2006a]). Operations during Expedition 308 included drilling three locations in Ursa Basin (Sites U1322U1324) on the continental slope of the Gulf of Mexico, offshore 
Louisiana in $\sim 1000 \mathrm{~m}$ water depth (Fig. F1). At Sites U1322 and U1324, a logging-while-drilling (LWD) hole and a coring hole were completed; at Site U1323, only a LWD hole was completed. Drilling was performed at a second location (Brazos-Trinity Basin IV) to compare observations made in Ursa Basin.

This synthesis paper summarizes operations and scientific studies performed during and after Expedition 308 with an emphasis on the study of fluid flow, overpressure, consolidation, and slope stability in continental margin sediments. We focus our discussion on the results within Ursa Basin. These studies have helped advance the high-priority goals of Expedition 308. Other research papers since the end of Expedition 308 include studies of sedimentology (Mallarino et al., 2006; Pirmez et al., in press), microbiology (Nunoura et al., 2009), rock magnetics (Fu et al., 2008), and pore pressure at Brazos-Trinity Basin IV (Schneider et al., 2009). A comprehensive listing of publications associated with Expedition 308 can be found at publications.iodp.org/proceedings/ 308/308bib.htm.

Expedition 308 was motivated by observations and models that suggested lateral flow could cause slope instability (Dugan and Flemings, 2000; Flemings et al., 2002). Rapid sediment loading drives overpressure $\left(u^{*}\right.$; pressure in excess of hydrostatic) in basins around the world (Rubey and Hubbert, 1959). In mudstone-rich environments, sedimentation can be rapid, permeability is low, and compressibility is high. In these environments, fluid flow cannot keep up with the sediment load, the fluids bear some of the sediment load, and pore pressures are greater than hydrostatic. Recent work has focused on how sedimentation and common stratigraphic architectures couple to produce two- and three-dimensional (3-D) flow fields (Flemings et al., 2002). For example, if a permeable sandstone body is rapidly loaded by low-permeability mudstone of varying thickness, fluids flow laterally within the aquifer to regions of low overburden before they are expelled into the bounding mudstone. This will create characteristic distributions of rock properties, fluid pressure, effective stress, temperature, and fluid chemistry in the aquifers and bounding mudstones. This process drives slope instability near the seafloor (Dugan and Flemings, 2000; Flemings et al., 2002); in the deeper subsurface, it drives fluids through low-permeability strata to ultimately vent at the seafloor (Boehm and Moore, 2002; Reilly and Flemings, 2010; Rubey and Hubbert, 1959; Seldon and Flemings, 2005). Expedition 308 documents the spatial variation in pressure, vertical stress, and rock properties in a flow-focusing environment.

\section{Regional studies and prior drilling in the Ursa Basin}

The Mars-Ursa salt-withdrawal basin (Ursa Basin) is $210 \mathrm{~km}$ south-southeast of New Orleans, Louisiana (USA), on the northeastern Gulf of Mexico continental slope (Fig. F1A). Late Pleistocene deposition from the ancestral Mississippi River is recorded by a southward bulge in the 500 and $1000 \mathrm{~m}$ bathymetric contours. Mars Ridge, a prominent north-south-trending bathymetric high, bounds the study area to the west (Fig. F1B).

The prolific Mars and Ursa oil fields lie at depths $>4000$ meters below seafloor (mbsf) in this region. Mahaffie (1994) described the geological character of the Mars oil field. The Ursa field is in Mississippi Canyon Blocks 855, 897, and 899 and is $11.9 \mathrm{~km}$ east of the Mars tension-leg platform.

Late Pleistocene strata in the Mars-Ursa region have received attention since the 1990s, when overpressured and unconsolidated sandstones in the shallow section plagued drilling operations (Ostermeier et al., 2002; Winker and Shipp, 2002). This drove the acquisition of high-resolution 3-D seismic data and geotechnical cores to study the geological and geotechnical framework in the region (Winker and Shipp, 2002).

Late Pleistocene shelf, shelf-margin, and turbidite deposits sourced from the Mississippi River are termed the eastern depositional complex. Eastern depositional complex strata in Ursa Basin accumulated outboard of the shelf break during marine isotope Stages (MIS) 2-4 in response to late Wisconsinan continental glaciation (Sawyer et al., 2007b; Winker and Booth, 2000; Winker and Shipp, 2002). Sawyer et al. (2007b) integrated 3-D seismic data with industry log data to characterize the shallow stratigraphy in this region. These strata are divided into the Blue Unit and overlying mudstone-prone leveed-channel deposition. The Blue Unit is a sandstone-dominated turbidite deposit that was formed in a broad topographic low that extended $200 \mathrm{~km}$ to the east and west and $100 \mathrm{~km}$ to the north and south (Pulham, 1993; Sawyer et al., 2007a; Winker and Booth, 2000). The overlying leveed-channel systems contain both channels and bounding levees.

Shell Oil Co. made downhole pressure measurements with a pore pressure penetrometer (piezoprobe) at the Ursa platform (Eaton, 1999; Ostermeier et al., 2002; Ostermeier, 2001). They also acquired whole-core samples and performed consolidation experiments to evaluate preconsolidation stress and estimate overpressure. Their work indicated that near the Ursa platform, overpressure begins near the sea- 
floor and that pore pressure is $\sim 50 \%$ between the hydrostatic pressure $\left(u_{\mathrm{h}}\right)$ and the overburden stress $\left(\sigma_{\mathrm{v}}\right)$.

\section{Expedition 308 drilling, coring, logging, and downhole measurements}

During Expedition 308, we drilled to just above the Blue Unit at three locations, Sites U1322-U1324 (Figs. F1, F2). At Site U1323 during the initial LWD phase, overpressured and unconsolidated sediments were encountered, resulting in flow of water and sand up the borehole (shallow-water flow) (see the "Expedition 308 summary" chapter [Expedition 308 Scientists, 2006a]). The well was terminated at $\sim 250$ mbsf, and no coring was accomplished at this location. We did core and make in situ pressure measurements at Sites U1322 and U1324.

\section{Stratigraphy}

Sawyer et al. (2009) described the stratigraphy of the drilling transect (Fig. F2). The leveed-channel systems above the Blue Unit contain sandstone channels and bounding levees. The Ursa Canyon channel-levee system immediately overlies the Blue Unit, whereas the Southwest Pass Canyon channel-levee system is younger and lies west of Ursa Canyon (Fig. F2). Mudstones above the Southwest Pass Canyon record deposition from leveed channels that lay further to the west, outside of the study area (Fig. F2B). Multiple mass transport deposits (MTDs) are present within the leveed-channel deposits. These MTDs are of the same composition as the mudstone-prone levee deposition.

Site U1324 is composed of lithostratigraphic Units I and II as defined by Expedition 308 (see the "Site U1324" chapter [Expedition 308 Scientists, 2006d]) (Fig. F3A). Unit I extends from 0 to $365 \mathrm{mbsf}$ and is composed of clay and silt; Unit II is composed of interbedded silt, sandstone, and clay and ranges from 365 to 604 mbsf (Fig. F3A). Seismic reflection S401324 lies at the boundary between these two lithofacies. Reflections between the seafloor and reflection S40-1324 are generally parallel and continuous and are controlled by minor changes in bulk density and velocity. Below reflection S40-1324, the responses of the seismic, gamma ray, resistivity, velocity, and bulk density logs are more variable. This variability is due in part to the variable lithology (interbedded sandstone, siltstone, and claystone) and in part to some hole washout within the sandstone intervals.

No core was collected at Site U1323; however, LWD logs were collected to 247 mbsf (Fig. F4). Three units were defined (see the "Site U1323" chapter [Expedition 308 Scientists, 2006c]). Logging Unit I extends from the seafloor to $197 \mathrm{mbsf}$ and is interpreted to be dominated by mudstone with several siltstone intervals and two MTDs (Fig. F4). At the top of logging Unit II, gamma ray and resistivity sharply decrease with depth, which is interpreted to record a transition downhole to sandstone. Logging Unit II cannot be correlated to Site U1324 or U1322. In logging Unit III, gamma ray values increase with depth, which suggests a downhole increase in clay content. At the base of logging Unit III (242 mbsf), a high-amplitude reflection correlates with relatively low gamma ray values; we interpret this to indicate sandstone.

Site U1322 is divided into lithostratigraphic Units I (0-125 mbsf) and II (125-238 mbsf) (see the "Site U1322" chapter [Expedition 308 Scientists, 2006b]) (Fig. F5A). These units are dominated by silty claystone, and the majority of the section is composed of MTDs, as illustrated by the white zones in Figure F2 and the purple zones in Figure F5A. MTDs are recorded by increased resistivity, increased bulk density, decreased porosity, and increased shear strength. The base of each MTD is marked by an abrupt decrease in density and increase in porosity with depth (Fig. F5C); this is recorded with a prominent negative (black) seismic reflection (Sawyer et al., 2009).

Eight coeval depositional surfaces were interpreted by Sawyer et al. (2009) (Fig. F2B). The base of the Blue Unit onlaps a regionally extensive condensed section, which contains the extinction events of the planktonic foraminifer Globorotalia flexuosa (70 ka) and the calcareous nannofossil Pontosphaera $1(\sim 70$ ka) (Styzen, 1995; Winker and Booth, 2000). The age of the top of the Blue Unit is unknown. Expedition 308 cored to within $\sim 20 \mathrm{~m}$ of the top of the Blue Unit at Sites U1324 and U1322 and recovered sediments younger than $57 \mathrm{ka}$ (see the "Expedition 308 summary" chapter [Expedition 308 Scientists, 2006]). At Site U1324, age markers of 48, 42, 24, 16, and $10 \mathrm{ka}$ were identified (Fig. F2B). At Site U1322, age markers of only $57,24,16$, and 10 ka were identified. However, the 57 and 24 ka markers are tentative because they were recovered within MTDs. We correlate these horizons across the transect with the exception of the 57,48 , and $42 \mathrm{ka}$ timelines because they were not identified at both Sites U1322 and U1324.

\section{Porosity}

The consolidation of sediment with depth at Ursa Basin was studied by Long et al. (2011). At Site U1324, porosity declines from $80 \%$ to $54 \%$ within 
the uppermost 50 mbsf (Fig. F3D). Between 50 and 520 mbsf, mudstone porosity gradually declines from $54 \%$ to $42 \%$. Finally, between 520 mbsf and the bottom of the hole (612 mbsf), porosity declines from $42 \%$ to $37 \%$. In the sandstone- and siltstonerich zones beneath 300 mbsf, the caliper log has high values, indicating borehole enlargement. High porosities are measured with the LWD logs in these intervals; Sawyer et al. (2009) interpret that the LWD density values are partially recording the open borehole.

At Site U1322, porosity decreases from $80 \%$ to $54 \%$ within the uppermost 50 mbsf; between 50 and 120 mbsf, porosity gradually declines to 44\% (Fig. F5D). Beneath this, porosity is approximately constant. At Site U1322, nearly the entire section is composed of silty claystone (Fig. F5A, F5B).

\section{Mass transport deposits}

MTDs are largely transparent in seismic data (Fig. F2). Log and core data demonstrate that MTDs are more dense than over- or underlying undeformed material (Sawyer et al., 2009; Strong, 2009). They are present at all three sites; however, Site U1322 has many more MTDs than Site U1324 (purple bedding in Figs. F3A, F5A). The best example of an MTD is illustrated at Site U1322 between 90 and 125 mbsf (Fig. F5). Sawyer et al. (2009) interpreted that the decreased porosity within MTDs (relative to the bounding sediment) resulted from vertical uniaxial consolidation during burial of a MTD that had been "remolded" during transport as a debris flow. Remolding destroys the soil fabric and deflocculates the material. As a result, the soil has higher compressibility and it compresses to a lower porosity at a given effective stress than it would have if it had not been remolded (Burland, 1990; Chandler, 2000; Mitchell, 1993; Skempton, 1969).

\section{Pressure}

A critical goal of Expedition 308 was to measure in situ pore pressure, one of the significant successes of the expedition (Flemings et al., 2008; Long et al., 2008a). We used the Davis-Villinger TemperaturePressure Probe (DVTPP) (Moore, Taira, Klaus, et al., 2001; Tréhu, Bohrmann, Rack, Torres, et al., 2003) and the temperature/dual pressure (T2P) probe (Flemings et al., 2006) to measure in situ pressure (Fig. F5). Pore pressure penetrometer data require significant interpretation, and different approaches are pursued (Flemings et al., 2008; Long et al., 2007). We describe the results from Sites U1324 and U1322 below. Long et al. (2008a) described the details of each deployment and how the tools were calibrated.
We plot overpressure versus depth beneath seafloor in Figures F3E and F5E. In these plots, pore pressure $(u)$ equals hydrostatic pressure when overpressure $\left(u^{*}\right)$ is zero, whereas pore pressure equals overburden stress $\left(\sigma_{v}\right)$ when overpressure $\left(u^{*}\right)$ equals hydrostatic effective stress $\left(\sigma_{\mathrm{vh}}{ }^{\prime}\right) . \sigma_{\mathrm{vh}}{ }^{\prime}$ is commonly referred to as reduced overburden stress $\left(\sigma_{\mathrm{vh}}{ }^{\prime}=\sigma_{\mathrm{v}}-u_{\mathrm{h}}\right)$ and is delineated with a solid black line in each plot (Figs. F3E, F5E). We also use the overpressure ratio $\left[\lambda^{*}=\left(u-u_{\mathrm{h}}\right) /\right.$ $\left.\left(\sigma_{v}-u_{\mathrm{h}}\right)\right]$ to characterize the relationship between pore pressure and overburden stress. When $\lambda^{*}=0$, overpressure equals zero and pore pressure is hydrostatic. When $\lambda^{*}=1$, pore pressure equals overburden stress.

At Site U1324, above 200 mbsf, severe overpressures parallel the reduced overburden stress, and $\lambda^{*}=0.7$ (Fig. F3E). Beneath 200 mbsf, overpressures are low and approximately equal to $1 \mathrm{MPa}$. Downhole pressures measured during drilling varied between 1.2 and $1.4 \mathrm{MPa}$ beneath 400 mbsf (PWD in Fig. F3E). When sandstones were penetrated, pressures dropped relative to mudstone penetration. We interpret that this pressure drop records flow from the borehole into the permeable formation (circulation loss) and that the downhole pressures are an upper bound to the formation pressure.

The overpressure distribution at Site U1324 is closely tied to lithology. Above 300 mbsf, where overpressure is high, the sediments are composed of monotonous hemipelagic silty claystone (Figs. F2, F3). At $305.7 \mathrm{mbsf}$, the first sandstone is encountered. This massive fine to medium sandstone is $1.1 \mathrm{~m}$ thick and is the coarsest sandstone bed encountered at Site U1324. It underlies the first decline in overpressure with depth, which is recorded at 250 mbsf. This sandstone lies within the eastern levee of Southwest Pass Canyon, which is otherwise dominated by clay and fine silt. It is truncated eastward between Sites U1324 and U1323 by a MTD, extends to the south, and ultimately intersects the channel fill of Southwest Pass Canyon (Sawyer et al., 2009). Its lateral continuity to the north and west is unknown. Beneath this sandstone, where overpressure is constant, silty claystone is interbedded with beds of silt and very fine sandstone (Fig. F3).

At Site U1322, overpressure increases linearly from the seafloor to 200 mbsf (Fig. F5). The sediments at Site U1322 are composed of silty claystone that is similar to the upper $200 \mathrm{~m}$ at Site U1324 (Fig. F3). The pore pressure relative to the overburden is slightly less at Site U1322 than at Site U1324 $\left(\lambda^{*}=\right.$ 0.6 versus $\left.\lambda^{*}=0.7\right)$. The deepest measurement (marked with a "?" in Fig. F5E) has relatively low pressure $(0.25 \mathrm{MPa})$ and is of high quality. A high- 
quality measurement occurs when there is significant dissipation over a long time (e.g., 15-30 min) and no tool dislodgement (Long et al., 2008a). The low pressure observed is contrary to the general trend of increasing overpressure with depth present at Site U1322 (Fig. F5E). This low pressure at the base of the hole may be caused by penetration and drainage of fluid from the Blue Unit during industry drilling since the mid-1990s (Flemings et al., 2008). Many of the wells that were drilled in this region penetrated the Blue Unit sandstone, and significant volumes of water and unconsolidated sand were expelled at the seafloor (Alberty, 2000).

\section{Laboratory analysis}

An extraordinary amount of whole core was taken during Expedition 308 that allowed for detailed geomechanical analyses (see the "Expedition 308 summary" chapter [Expedition 308 Scientists, 2006]). Grain size analyses were performed (Sawyer et al., 2008) in addition to clay mineralogy analysis (John and Adatte, 2009). Long et al. (2008b) described the compression behavior and the permeability of the Ursa Basin mudstones. Long et al. (2011) showed that the compression behavior observed in the laboratory was similar to the field compression behavior. Schneider (2011) analyzed the Long et al. (2008b) results and quantified an exponential relationship between porosity and permeability. Dugan and Germaine (2009) completed triaxial strength experiments on specimens from Sites U1322 and U1324 and documented internal friction angles from $17^{\circ}$ to $29^{\circ}$.

\section{Synthesis through modeling}

A range of hydrodynamic modeling has been performed on data from the Ursa system based on the results from Expedition 308 (Binh et al., 2010; Dugan and Stigall, 2010; Flemings et al., 2008; Stigall and Dugan, 2010; Urgeles et al., 2010). See Table T1 for a list of consolidation nomenclature used during Expedition 308. All of these models follow the consolidation equation

$$
D u / D t=\left(k / \mu m_{\mathrm{v}}\right) \nabla^{2} u^{*}+\left(D \sigma_{\mathrm{v}} / D t\right)
$$

where

$$
\begin{aligned}
& u=\text { pressure, } \\
& k=\text { permeability, } \\
& \mu=\text { dynamic viscosity, and } \\
& D \sigma_{\mathrm{v}} / D t=\text { the loading rate from sedimentation. }
\end{aligned}
$$

$m_{\mathrm{v}}$, the uniaxial compressibility, is defined by

$$
m_{\mathrm{v}}=-\left[\left(1 / d \sigma_{\mathrm{v}}\right)(d V / V)\right]=[-d e /(1+e)]\left(1 / d \sigma_{\mathrm{v}}\right),
$$

where $V$ is the bulk volume. The coefficient of consolidation $\left(c_{\mathrm{v}}\right)$, often termed the hydraulic diffusivity, is

$$
c_{\mathrm{v}}=k / \mu m_{\mathrm{v}}
$$

Overpressure is generated when the loading rate by sedimentation $\left(D \sigma_{\mathrm{v}} / D t\right)$ outpaces the rate at which pressure can dissipate $\left(c_{\mathrm{v}} \nabla^{2} u^{*}\right)$. Gibson (1958) presented an analytical solution for Equation 1 and showed that the degree of overpressure is controlled by the dimensionless time factor $\left(T_{\mathrm{g}}\right)$ :

$$
T_{\mathrm{g}}=m^{2} t / c_{\mathrm{v}}
$$

where $m$ is sedimentation rate and $t$ is total time. $T_{g}$ $>\sim 1.0$ results in significant overpressure (Flemings et al., 2008; Gibson, 1958).

We use both experimental results and in situ observations to describe the porosity $(n)$, permeability $(k)$, compressibility $\left(m_{\mathrm{v}}\right)$, and coefficient of consolidation $\left(c_{\mathrm{v}}\right)$ for the three characteristic lithofacies encountered: mudstone, MTD, and siltstone (Fig. F6; Table T1).

Permeability as a function of effective stress was explored by Long et al. (2008b) and Schneider (2011). We describe permeability as an exponential function of porosity:

$$
k=k_{0} 10^{\mathrm{m}},
$$

where $n$ is porosity and $\gamma$ and $k_{\mathrm{o}}$ are empirically derived from experimental work. We performed 29 constant rate of strain (CRS) experiments on Ursa Basin mudstones to determine the permeability of individual core samples at a range of porosities (Long et al., 2008b). From these data, we calculated the harmonic average of the permeabilities at a range of porosities. We used linear regression on these averaged data to determine $k_{\mathrm{o}}$ and $\gamma$ (Equation 5) for the mudstone lithofacies (Table T1). We assume that the harmonically averaged relationship describes the vertical permeability. We compared mudstones from within MTDs to undeformed samples and could find no distinguishable difference in the permeability-porosity relationship. Thus, we describe the permeability behavior of the MTD lithofacies using the same parameters as those of the mudstone lithofacies. Long et al. (2008b) presented one CRS test on siltstone and we use these measurements to describe siltstone lithofacies permeability (Table T1). 
Long et al. (2011) used CRS experiments to determine the compression behavior of mudstones. They described the in situ porosity-effective stress behavior with

$$
1+e=\left(1+e_{0}\right)\left(\sigma_{\mathrm{v}}{ }^{\prime} / \sigma_{0}\right)^{c},
$$

where $e_{\mathrm{o}}$ is the void ratio at an effective stress of unity, and $\sigma_{0}$ is the reference stress, which we choose as $1 \mathrm{MPa}$. Long et al. (2011) find $\mathrm{C}=-0.0979$ and $e_{\mathrm{o}}=$ 0.89 at $1 \mathrm{MPa}$ when units of MPa are used (Table T2). As discussed, at a given effective stress the MTDs are more compressed (lower void ratio) than the undeformed mudstone. We assume for the MTD that the exponent $\mathrm{C}$ is the same as that for the mudstone. However, we assume a lower value for $e_{\mathrm{o}}$ such that on a $\log (e+1)-\log \left(\sigma_{v}{ }^{\prime}\right)$ plot the compression line for the MTD lithofacies is moved to the left half a log cycle $\left(10^{0.5}\right)$ from the compression line of the mudstone lithofacies (Table T2).

The compression behavior of the siltstone lithofacies (Table T2) is based on a single CRS test (Long et al., 2008b). This compression behavior is best described using a conventional soil model where

$$
e=e_{\mathrm{o}}+\lambda \log _{10}\left(\sigma_{\mathrm{v}}{ }^{\prime} / \sigma_{0}\right),
$$

where $e_{0}$ is the void ratio at an effective stress of unity and $\sigma_{0}$ is the reference stress, which we choose as $1 \mathrm{MPa}$. We discuss the behavior of porosity $(n)$, permeability $(k)$, compressibility $\left(m_{\mathrm{v}}\right)$, and coefficient of consolidation $\left(c_{v}\right)$ over a stress range from 0.01 to $10 \mathrm{MPa}$ (Fig. F6). This stress range corresponds approximately to "hydrostatic" depths (the depth if the pore pressure were hydrostatic) of 1 to $1000 \mathrm{~m}$ (Fig. F6, right side). The actual effective stress range encountered during Expedition 308 drilling ranges from 0 to $\sim 4 \mathrm{MPa}$ (the difference between the reduced overburden stress and the overpressure at the deepest location at Site U1324) (Fig. F3).

The porosity of the siltstone lithofacies is everywhere less than that of the mudstone or MTD lithofacies (Fig. F6A). However, the siltstone lithofacies declines less with increasing stress than does the mudstone or MTD lithofacies. At a given effective stress, the porosity of the MTD is $\sim 5$ porosity units less than the mudstone.

Permeability declines with increasing effective stress for each lithofacies because they have lower porosity at higher stresses (Fig. F6A, F6B). The mudstone and MTD lithofacies have lower permeability than the siltstone lithofacies because they are composed of finer material (Fig. F6B). At $0.1 \mathrm{MPa}$, mudstone permeability is less than 1 order of magnitude less than siltstone permeability, whereas at an effective stress of $10 \mathrm{MPa}$, it is almost two orders of magnitude less. The permeability of the mudstone lithofacies declines more with increasing effective stress than that of the siltstone lithofacies. The mudstone and MTD lithofacies compress more with increasing effective stress than the siltstone lithofacies, and this causes the larger drop in permeability with effective stress (Fig. F6A, F6B). The MTD lithofacies has a lower permeability at a given effective stress than the mudstone lithofacies because it is has lower porosity.

Uniaxial compressibility $\left(m_{\mathrm{v}}\right)$ is calculated from the void ratio-effective stress relationship (Equation 2). $m_{\mathrm{v}}$ declines by 3 orders of magnitude from $0.01 \mathrm{MPa}$ to $10 \mathrm{MPa}$ (Fig. F6C). This large decrease in compressibility (increase in stiffness) results from the loss of porosity (Fig. F6A) and consequent increase in grain to grain contact. The compressibility of the mudstone lithofacies is the same as that of the MTD lithofacies. The compressibility of the siltstone lithofacies is less than that of the mudstone lithofacies (Fig. F6C).

The coefficient of compressibility $\left(c_{v}\right)$ is calculated from Equation 3 based on the permeability and compressibility described above and assuming a viscosity of $1 \times 10^{-3} \mathrm{~Pa} \cdot \mathrm{s}$. In the mudstone, between 0.1 and 1 $\mathrm{MPa}$, the coefficient of consolidation $\left(c_{\mathrm{v}}\right)$ is fairly constant and equal to $1 \times 10^{-8} \mathrm{~m}^{2} / \mathrm{s}$. At higher and lower values of effective stress, $c_{\mathrm{v}}$ is slightly lower (Fig. F6D). $c_{\mathrm{v}}$ is constant because compressibility and permeability decrease at the same rate as effective stress increases (Equation 3; Fig. F6). The MTD coefficient of consolidation is $\sim 5$ times lower. This is driven entirely by the lower permeability within the MTD at a given stress. The coefficient of consolidation for siltstone ranges from $3 \times 10^{-8} \mathrm{~m}^{2} / \mathrm{s}$ at 0.01 $\mathrm{MPa}$ to $5 \times 10^{-7} \mathrm{~m}^{2} / \mathrm{s}$ at $10 \mathrm{MPa}$.

We calculate the dimensionless time factor $T_{\mathrm{g}}$ (Equation 4). At Site U1324, for the mudstone lithofacies we assume a sedimentation rate of $12 \mathrm{~mm} / \mathrm{y}, c_{\mathrm{v}}=1 \times$ $10^{-8} \mathrm{~m}^{2} / \mathrm{s}$ and a duration $(t)$ of $50,000 \mathrm{y}$. We find $T_{\mathrm{g}}=$ 23 , which results in $\lambda^{*}=0.75$ at the base of the section; even higher values are present in the shallower section. At Site U1322, for the mudstone lithofacies we assume a sedimentation rate of $4 \mathrm{~mm} / \mathrm{y}$ and find $T_{\mathrm{g}}=2.5$. In contrast, the siltstone lithofacies, with $c_{\mathrm{v}}$ $=\sim 2 \times 10^{-7} \mathrm{~m}^{2} / \mathrm{s}$, produces $T_{\mathrm{g}}=1.0$ at; this results in no significant overpressure. Similar calculations were presented by Flemings et al. (2008).

In summary, one of the fundamental results of Expedition 308 is that we have shown that rapid sedimentation of the highly compressible mudstones at Ursa Basin results in significant overpressures from 
the seafloor downward. This result contrasts with the historical view that overpressure is encountered only at greater depths (Dickinson, 1953). The absence of overpressure at shallow depths on the continental shelf inspired theoretical models suggesting that mudstones could only become pressure seals after their porosity was sufficiently reduced by burial (Mello et al., 1994). Expedition 308 results show that outboard of deltaic systems on the continental slope, rapid deposition of fine-grained and compressible sediment creates ideal conditions for overpressure generation.

Several authors modeled the Ursa system in two dimensions (Binh et al., 2010; Dugan and Stigall, 2010; Stigall and Dugan, 2010; Urgeles et al., 2010). They illustrate that flow focusing is present in Ursa Basin. Stigall and Dugan (2010) show that fluids are driven from the zone where the overburden is thick at Site U1324 toward the section where it is thin at Site U1322 along the more permeable beds of the underlying Blue Unit (Fig. F7B). In addition, they illustrate that in the more permeable siltstones present in the bottom half of Site U1324, overpressure is approximately constant (Figs. F3, F7).

A striking result of our study is that submarine landslides all lie within zones of high overpressure $\left(\lambda^{*}>\right.$ 0.6) (purple zones in Figs. F3A, F5A). High pore pressure increases the risk of landslides for a given slope (Dugan and Flemings, 2002). For a constant friction angle $\left(\phi_{f}\right)$ and sediment with no cohesion, the factor of safety (FS) is proportional to the overpressure ratio $\left(\lambda^{*}\right)$

$$
\mathrm{FS}=\left(\tan \phi_{\mathrm{f}} / \sin \theta \cos \theta\right)\left(\cos ^{2} \theta-\lambda^{*}\right),
$$

where $\theta$ is the surface slope. At Ursa Basin, all locations are stable today (FS > 1.0) (Flemings et al., 2008; Sawyer et al., 2009). However, Stigall and Dugan (2010) showed that the deeper zones at Site U1322 were unstable during times of rapid sedimentation soon after deposition of the Blue Unit and that these zones correlate to locations where MTDs are present. Stigall and Dugan (2010) also suggested that the largest MTD (MTD-2 in Fig. F2B) may have resulted from the combination of moderate overpressure from rapid sedimentation coupled with horizontal earthquake acceleration of a magnitude 5 earthquake within $140 \mathrm{~km}$ or a magnitude 4 earthquake within $3 \mathrm{~km}$ of the Ursa region. There is no record of earthquakes from the time MTD-2 was formed (27-10 ka). However, seismicity from 1973 to 2009 records an earthquake of magnitude 5 within $140 \mathrm{~km}$ of Ursa Basin location (Stigall and Dugan, 2010).
The northern continental slope in the Gulf of Mexico has the lowest gradient of the U.S. continental margins, and it has the largest submarine landslides (McAdoo et al., 2000). We interpret that overpressures precondition the slope for failure and that earthquakes may induce the failures and keep the continental slope at a low gradient. Thus, high pore pressure near the seafloor plays a significant role in controlling where submarine landslides occur and controlling the topographic gradient of the continental slope.

\section{Summary of hydrogeologic findings and plans for future work}

Expedition 308 documented high overpressures. At Site U1324, overpressures are $70 \%$ of the hydrostatic effective stress to a depth of $200 \mathrm{mbsf}\left(\lambda^{*}=\sim 0.7\right)$. Beneath this, overpressures drop significantly and are approximately equal to $1 \mathrm{MPa}$ to a depth of 600 mbsf. The shallow overpressures are present in very rapidly deposited, low-permeability mudstone, whereas the deeper zone where the overpressure is lower is composed of interbedded siltstone, mudstone, and sandstone. At Site U1322, the overpressures are $60 \%$ of the hydrostatic effective stress $\left(\lambda^{*}=\right.$ $0.6)$ to 200 mbsf through a uniform mudstone section.

Permeability and compressibility of Ursa Basin mudstones decline significantly with depth near the seafloor. As a result, the coefficient of consolidation (hydraulic diffusivity) is approximately constant at 1 $\times 10^{-8} \mathrm{~m}^{2} / \mathrm{s}$ over the depth range drilled. Given the sedimentation rates in the Ursa region, sedimentation alone can account for the severe overpressures observed at Site U1324. However, one-dimensional modeling cannot explain the high pore pressures observed at Site U1322. In this location, modeling shows that the more rapid sedimentation at Site U1324 than at Site U1322 is driving flow laterally within the permeable Blue Unit. This elevates the pore pressures at Site U1322 and reduces them slightly at Site U1324.

Two-dimensional models also show that the deeper zones at Site U1322 were unstable during times of rapid sedimentation, soon after deposition of the Blue Unit; these zones correlate to locations where MTDs are present (Stigall and Dugan, 2010). The largest MTD (MTD-2 in Fig. F2B) may have resulted from the combination of moderate overpressure from rapid sedimentation coupled with horizontal 
earthquake acceleration of a magnitude 5 earthquake within $140 \mathrm{~km}$ of the Ursa region (Stigall and Dugan, 2010).

MTDs have a unique signature in log, core, and seismic data. We interpret that these deposits are remolded during mass transport and as a result they follow a unique compression curve that results in lower porosity at a given effective stress.

An original goal of Expedition 308 was to measure and monitor pore pressure within the Blue Unit at multiple locations to confirm the pore fluid pressure distribution in this aquifer. Future work will focus on long-term monitoring of pressure in both the Blue Unit and in over- and underlying mudstones. These measurements will allow us to constrain whether significant lateral flow is occurring within the Blue Unit, what the hydraulic connectivity of the Blue Unit is, and what the permeability of the Blue Unit is. Pressure monitoring may also allow us to image ongoing deformation occurring due to submarine landslides.

\section{Acknowledgments}

We are indebted to the extraordinary efforts of the technical staff on the R/V JOIDES Resolution during Expedition 308. This work was supported by the U.S. National Science Foundation (NSF) (OCE 0351085 and EAR 0447235), the UT GeoFluids consortium at The University of Texas, Austin (www.beg.utexas.edu/ geofluids/) (supported by 11 energy companies), the Petroleum Research Fund (PRF 44476-AC8), the Pennsylvania State Geofluids Consortium, and Joint Oceanographic Institutions, Inc.-United States Science Advisory Committee Expedition 308 support to Flemings, Long, Germaine, and others. This research builds on insights derived from samples and/or data provided by the Integrated Ocean Drilling Program (IODP). IODP is sponsored by NSF and participating countries. We thank Shell Oil and the other Ursa region partners for access to seismic and well log data. Landmark Graphics Seisworks 3-D, Paradigm Geolog, and the freeware Generic Mapping Tool program were the primary software tools used in this study. Yao You, Derek Sawyer, and Julia Schneider provided helpful technical input. This paper is The University of Texas Institute for Geophysics contribution 2450. Publication authorized by the Director, Bureau of Economic Geology, The University of Texas.

\section{References}

Alberty, M., 2000. Shallow water flows: a problem solved or a problem emerging. Proc.-Annu. Offshore Technol. Conf., 1-7.

Binh, N.T.T., Tokunaga, T., Nakamura, T., Kozumi, K., Nakajima, M., Kubota, M., Kameya, H., and Taniue, M., 2010. Physical properties of shallow sediments in late Pleistocene formations, Ursa Basin, Gulf of Mexico, and their implications for generation and preservation of shallow overpressures. Mar. Pet. Geol., 26(4):474-486. doi:10.1016/j.marpetgeo.2009.01.018

Boehm, A., and Moore, J.C., 2002. Fluidized sandstone intrusions as an indicator of paleostress orientation, Santa Cruz, California. Geofluids, 2(2):147-161. doi:10.1046/j.1468-8123.2002.00026.x

Burland, J.B., 1990. On the compressibility and shear strength of natural clays. Geotechnique, 40:329-378.

Chandler, R.J., 2000. The Third Glossop Lecture-clay sediments in depositional basins: the geotechnical cycle. $Q$. J. Eng. Geol. Hydrogeol., 33(1):7-39. doi:10.1144/ qjegh.33.1.7

Dickinson, G., 1953. Geological aspects of abnormal reservoir pressures in Gulf Coast Louisiana. AAPG Bull., 37(2):410-432.

Dugan, B., and Flemings, P.B., 2000. Overpressure and fluid flow in the New Jersey continental slope: implications for slope failure and cold seeps. Science, 289(5477):288-291. doi:10.1126/science.289.5477.288

Dugan, B., and Flemings, P.B., 2002. Fluid flow and stability of the US continental slope offshore New Jersey from the Pleistocene to the present. Geofluids, 2(2):137-146. doi:10.1046/j.1468-8123.2002.00032.x

Dugan, B., and Germaine, J.T., 2009. Data report: strength characteristics of sediments from IODP Expedition 308, Sites U1322 and U1324. In Flemings, P.B., Behrmann, J.H., John, C.M., and the Expedition 308 Scientists, Proc. IODP, 308: College Station, TX (Integrated Ocean Drilling Program Management International, Inc.). doi:10.2204/iodp.proc.308.210.2009

Dugan, B., and Stigall, J., 2010. Origin of overpressure and slope failure in the Ursa region, northern Gulf of Mexico. In Mosher, D.C., Shipp, C., Moscardelli, L., Chaytor, J., Baxter, C., Lee, H., and Urgeles, R. (Eds.), Submarine Mass Movements and Their Consequences. Adv. Nat. Tech. Hazards Res., 28(4):167-178. doi:10.1007/978-90-4813071-9_14

Eaton, L.F., 1999. Drilling through deepwater shallow water flow zones at Ursa. Proc.—SPE/IADC Middle East Drill. Conf., 153-164.

Expedition 308 Scientists, 2006a. Expedition 308 summary. In Flemings, P.B., Behrmann, J.H., John, C.M., 
and the Expedition 308 Scientists, Proc. IODP, 308: College Station, TX (Integrated Ocean Drilling Program Management International, Inc.). doi:10.2204/ iodp.proc.308.101.2006

Expedition 308 Scientists, 2006b. Site U1322. In Flemings, P.B., Behrmann, J.H., John, C.M., and the Expedition 308 Scientists, Proc. IODP, 308: College Station, TX (Integrated Ocean Drilling Program Management International, Inc.). doi:10.2204/iodp.proc.308.106.2006

Expedition 308 Scientists, 2006c. Site U1323. In Flemings, P.B., Behrmann, J.H., John, C.M., and the Expedition 308 Scientists, Proc. IODP, 308: College Station, TX (Integrated Ocean Drilling Program Management International, Inc.). doi:10.2204/iodp.proc.308.107.2006

Expedition 308 Scientists, 2006d. Site U1324. In Flemings, P.B., Behrmann, J.H., John, C.M., and the Expedition 308 Scientists, Proc. IODP, 308: College Station, TX (Integrated Ocean Drilling Program Management International, Inc.). doi:10.2204/iodp.proc.308.108.2006

Flemings, P.B., Germaine, J., Long, H., Dugan, B., Sawyer, D., Behrmann, J.H., and John, C., 2006. Measuring temperature and pressure with the temperature two pressure (T2P) probe in the Ursa Basin, Gulf of Mexico: development of a new pressure and temperature probe for the IODP. Proc.-Annu. Offshore Technol. Conf., 38. doi:10.4043/17957-MS

Flemings, P.B., Long, H., Dugan, B., Germaine, J., John, C.M., Behrmann, J.H., Sawyer, D., and IODP Expedition 308 Scientists, 2008. Erratum to "Pore pressure penetrometers document high overpressure near the seafloor where multiple submarine landslides have occurred on the continental slope, offshore Louisiana, Gulf of Mexico" [Earth and Planetary Science Letters 269/34(2008)309-32]. Earth Planet. Sci. Lett., 274(1-2):269283. doi:10.1016/j.eps1.2008.06.027

Flemings, P.B., Stump, B.B., Finkbeiner, T., and Zoback, M., 2002. Flow focusing in overpressured sandstones: theory, observations, and applications. Am. J. Sci., 302:827855. doi:10.2475/ajs.302.10.827

Fu, Y., von Dobeneck, T., Franke, C., Heslop, D., and Kasten, S., 2008. Rock magnetic identification and geochemical process models of greigite formation in Quaternary marine sediments from the Gulf of Mexico (IODP Hole U1319A). Earth Planet. Sci. Lett., 275(34):233-245. doi:10.1016/j.epsl.2008.07.034

Gibson, R.E., 1958. The progress of consolidation in a clay layer increasing in thickness with time. Geotechnique, 8:171-182.

John, C.M., and Adatte, T., 2009. Data report: X-ray analyses of bulk sediment in IODP Holes U1320A and U1324B, northern Gulf of Mexico. In Flemings, P.B., Behrmann, J.H., John, C.M., and the Expedition 308 Scientists, Proc. IODP, 308: College Station, TX (Integrated Ocean Drilling Program Management International, Inc.). doi:10.2204/iodp.proc.308.214.2009

Long, H., Flemings, P.B., Dugan, B., Germaine, J.T., and Ferrell, D., 2008a. Data report: penetrometer measurements of in situ temperature and pressure, IODP Expedition 308. In Flemings, P.B., Behrman, J.H., John, C.M., and the Expedition 308 Scientists, Proc. IODP, 308: Col- lege Station, TX (Integrated Ocean Drilling Program Management International, Inc.). doi:10.2204/ iodp.proc.308.203.2008

Long, H., Flemings, P.B., and Germaine, J.T., 2007. Interpreting in situ pressure and hydraulic properties with borehole penetrometers in ocean drilling: DVTPP and piezoprobe deployments at southern Hydrate Ridge, offshore Oregon. J. Geophys. Res., [Solid Earth], 112(B4):B04101. doi:10.1029/2005JB004165

Long, H., Flemings, P.B., Germaine, J.T., and Saffer, D.M., 2011. Consolidation and overpressure near the seafloor in the Ursa Basin, deepwater Gulf of Mexico. Earth Planet. Sci. Lett., 305(1-2):11-20. doi:10.1016/ j.eps1.2011.02.007

Long, H., Flemings, P.B., Germaine, J.T., Saffer, D.M., and Dugan, B., 2008b. Data report: consolidation characteristics of sediments from IODP Expedition 308, Ursa Basin, Gulf of Mexico. In Flemings, P.B., Behrmann, J.H., John, C.M., and the Expedition 308 Scientists, Proc. IODP, 308: College Station, TX (Integrated Ocean Drilling Program Management International, Inc.). doi:10.2204/iodp.proc.308.204.2008

Mahaffie, M.J., 1994. Reservoir classification for turbidite intervals at the Mars discovery, Mississippi Canyon Block 807, Gulf of Mexico. In Bouma, A.H., and Perkins, B.G. (Eds.), Submarine Fans and Turbidite Systems. GCSSEPM Found. 15th Annu. Res. Conf. Program Abstr., 233-244.

Mallarino, G., Beaubouef, R.T., Droxler, A.W., Abreu, V., and Labeyrie, L., 2006. Sea level influence on the nature and timing of a minibasin sedimentary fill (northwestern slope of the Gulf of Mexico). AAPG Bull., 90(7):1089-1119. doi:10.1306/02210605058

McAdoo, B.G., Pratson, L.F., and Orange, D.L., 2000. Submarine landslide geomorphology, US continental slope. Mar. Geol., 169(1-2):103-136. doi:10.1016/S00253227(00)00050-5

Mello, U.T., Karner, G.D., and Anderson, R.N., 1994. A physical explanation for the positioning of the depth to the top of overpressure in shale-dominated sequences in the Gulf Coast Basin, United States. J. Geophys. Res., [Solid Earth], 99(B2):2775-2789. doi:10.1029/ 93JB02899

Mitchell, J.K., 1993. Fundamentals of Soil Behavior (2nd ed.): New York (Wiley).

Moore, G.F., Taira, A., Klaus, A., et al., 2001. Proc. ODP, Init. Repts., 190: College Station, TX (Ocean Drilling Program). doi:10.2973/odp.proc.ir.190.2001

Nunoura, T., Soffientino, B., Blazejak, A., Kakuta, J., Oida, H., Schippers, A., and Takai, K., 2009. Subseafloor microbial communities associated with rapid turbidite deposition in the Gulf of Mexico continental slope (IODP Expedition 308). FEMS Microbiol. Ecol., 69(3):410424. doi:10.1111/j.1574-6941.2009.00718.x

Ostermeier, R.M., Pelletier, J.H., Winker, C.D., and Nicholson, J.W., 2001. Trends in shallow sediment pore pressures-deepwater Gulf of Mexico. Proc.-SPE/IADC Drill. Conf., 1-11. doi:10.2118/67772-MS

Ostermeier, R.M., Pelletier, J.H., Winker, C.D., Nicholson, J.W., Rambow, F.H., and Cowan, K.M., 2002. Dealing 
with shallow-water flow in the deepwater Gulf of Mexico. Leading Edge, 21(7):660, 662-668. doi:10.1190/ 1.1497320

Pirmez, C., Prather, B., Mallarino, G., Ohayer, W., Droxler, A., and Winker, C., in press. Chronostratigraphy of the Brazos-Trinity depositional system, western Gulf of Mexico: implications for deepwater depositional models. In Prather, B.E., Deptuck, M.E., Mohrig, D.C., van Hoorn, B., and Wynn, R.B. (Eds.), Application of Seismic Geomorphology Principles to Continental Slope and Base-ofslope Systems: Case Studies from Seafloor and Near-Seafloor Analogues. Spec. Publ._SEPM (Soc. Sediment. Geol.).

Pulham, A.J., 1993. Variations in slope deposition, Pliocene-Pleistocene, offshore Louisiana, northeast Gulf of Mexico. In Posamentier, H., and Weimer, P. (Eds.), Siliclastic Sequence Stratigraphy: Recent Developments and Applications. AAPG Mem., 58:199-233.

Reilly, M.J., and Flemings, P.B., 2010. Deep pore pressures and seafloor venting in the Auger Basin, Gulf of Mexico. Basin Res., 22(4):380-397. doi:10.1111/j.13652117.2010.00481.x

Rubey, W.W., and Hubbert, M.K., 1959. Role of fluid pressure in mechanics of overthrust faulting, Part 2. Overthrust belt in geosynclinal area of western Wyoming in light of fluid-pressure hypothesis. Geol. Soc. Am. Bull., 70(2):167-206. doi:10.1130/00167606(1959)70[167:ROFPIM]2.0.CO;2

Sawyer, D.E., Flemings, P., and Dugan, B., 2007a. Lateral variations in core, $\log$, and seismic attributes of a mass transport complex in the Ursa region, IODP Expedition 308, Northern Gulf of Mexico. Proc.-Annu. Offshore Technol. Conf., 39. doi:10.4043/19098-MS

Sawyer, D.E., Flemings, P.B., Dugan, B., and Germaine, J.T., 2009. Retrogressive failures recorded in mass transport deposits in the Ursa Basin, northern Gulf of Mexico. J. Geophys. Res., [Solid Earth], 114(B10):B10102. doi:10.1029/2008JB006159

Sawyer, D.E., Flemings, P.B., Shipp, R.C., and Winker, C.D., 2007b. Seismic geomorphology, lithology, and evolution of the late Pleistocene Mars-Ursa turbidite region, Mississippi Canyon area, northern Gulf of Mexico. AAPG Bull., 91(2):215-234. doi:10.1306/08290605190

Sawyer, D.E., Jacoby, R., Flemings, P.B., and Germaine, J.T., 2008. Data report: particle size analysis of sediments in the Ursa Basin, IODP Expedition 308 Sites U1324 and U1322, northern Gulf of Mexico. In Flemings, P.B., Behrmann, J.H., John, C.M., and the Expedition 308 Scientists, Proc. IODP, 308: College Station, TX (Integrated Ocean Drilling Program Management International, Inc.). doi:10.2204/iodp.proc.308.205.2008

Schneider, J., 2011. Compression and permeability behavior of natural mudstones [Ph.D. thesis]. Univ. Texas, Austin. http://hdl.handle.net/2152/ETD-UT-2011-124730

Schneider, J., Flemings, P.B., Dugan, B., Long, H., and Germaine, J.T., 2009. Overpressure and consolidation near the seafloor of Brazos-Trinity Basin IV, northwest deepwater Gulf of Mexico. J. Geophys. Res., [Solid Earth], 114(B5):B05102. doi:10.1029/2008JB005922

Seldon, B., and Flemings, P.B., 2005. Reservoir pressure and seafloor venting: predicting trap integrity in a Gulf of Mexico deepwater turbidite minibasin. AAPG Bull., 89(2):193-209.

Skempton, A.W., 1969. The consolidation of clays by gravitational compaction. Q. J. Geol. Soc. London, 125(14):373-411. doi:10.1144/gsjgs.125.1.0373

Stigall, J., and Dugan, B., 2010. Overpressure and earthquake initiated slope failure in the Ursa region, northern Gulf of Mexico. J. Geophys. Res., [Solid Earth], 115(B4):B04101. doi:10.1029/2009JB006848

Strong, H.E., 2009. The origin and properties of mass transport deposits, Ursa Basin, Gulf of Mexico [Ph.D. thesis]. Univ. Texas, Austin. http://hdl.handle.net/2152/ETDUT-2009-12-440

Styzen, M.J., 1995. A chart in two sheets of the late Cenozoic chronostratigraphy of the Gulf of Mexico. In Travis, C.J. (Ed.), Salt, Sediment and Hydrocarbons. GCSSEPM Found. 16th Annu. Res. Conf. Program Abstr.

Tréhu, A.M., Bohrmann, G., Rack, F.R., Torres, M.E., et al., 2003. Proc. ODP, Init. Repts., 204: College Station, TX (Ocean Drilling Program). doi:10.2973/ odp.proc.ir.204.2003

Urgeles, R., Locat, J., Sawyer, D.E., Flemings, P.B., Dugan, B., and Binh, N.T.T., 2010. History of pore pressure build up and slope instability in mud-dominated sediments of Ursa Basin, Gulf of Mexico continental slope. In Mosher, D.C., Shipp, R.C., Moscardelli, L., Chaytor, J.D., Baxter, C.D.P., Lee, H.J., and Urgeles, R. (Eds.), Submarine Mass Movements and Their Consequences: 4th International Symposium. Adv. Nat. Tech. Hazards Res., 28(1):179-190. doi:10.1007/978-90-481-3071-9_15

Winker, C.D., and Booth, J.R., 2000. Sedimentary dynamics of the salt-dominated continental slope, Gulf of Mexico: integration of observations from the seafloor, near-surface, and deep subsurface. In Weimer, P., Slatt, R.M., Coleman, J., Rosen, N.C., Nelson, H., Bouma, A.H., Styzen, M.J., and Lawrence, D.T. (Eds.), Deep-Water Reservoirs of the World. GCSSEPM Found. 20th Annu. Res. Conf. Program Abstr., 1059-1086.

Winker, C.D., and Shipp, R.C., 2002. Sequence stratigraphic framework for prediction of shallow water flow in the greater Mars-Ursa area, Mississippi Canyon area, Gulf of Mexico continental slope. In Armentrout, J.M., and Rose, N.C. (Eds.), Sequence Stratigraphic Models for Exploration and Production: Evolving Methodology, Emerging Models and Application Histories. GCSSEPM Found. 22nd Annu. Res. Conf. Program Abstr., 42.

Initial receipt: 1 June 2010

Acceptance: 2 February 2012

Publication: 10 April 2012

MS 308-215 
Figure F1. A. Bathymetry image showing the Ursa region $210 \mathrm{~km}$ southeast of New Orleans, Louisiana (USA). B. IODP drilling transect located in 1000-1300 m water depth. Expedition 308 sites are shown with yellow circles. The Ursa and Mars oil fields are overlain by the Ursa and Mars tension-leg platforms (TLP; squares). Industry well MC 899-1 is shown with a white circle. CI = contour interval.

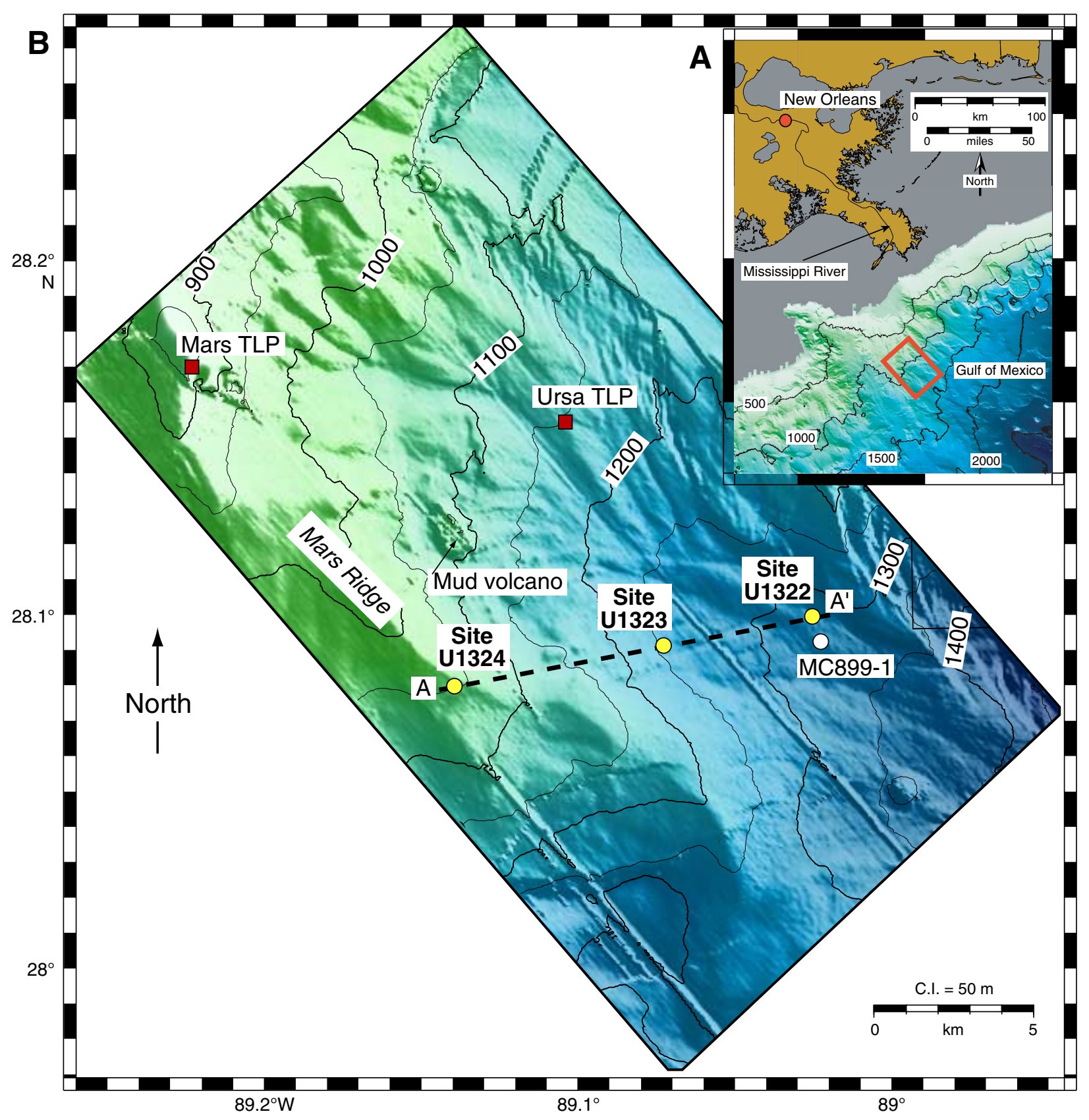


Figure F2. A. Depth-converted seismic cross-section A-A' tied with Expedition 308 holes. Gamma ray (GR) and resistivity (RES) LWD logs are shown as well as key seismic surfaces. Solid lines represent age-equivalent horizons that have been identified at IODP sites. Dashed lines represent tentative time lines. (Continued on next page.)

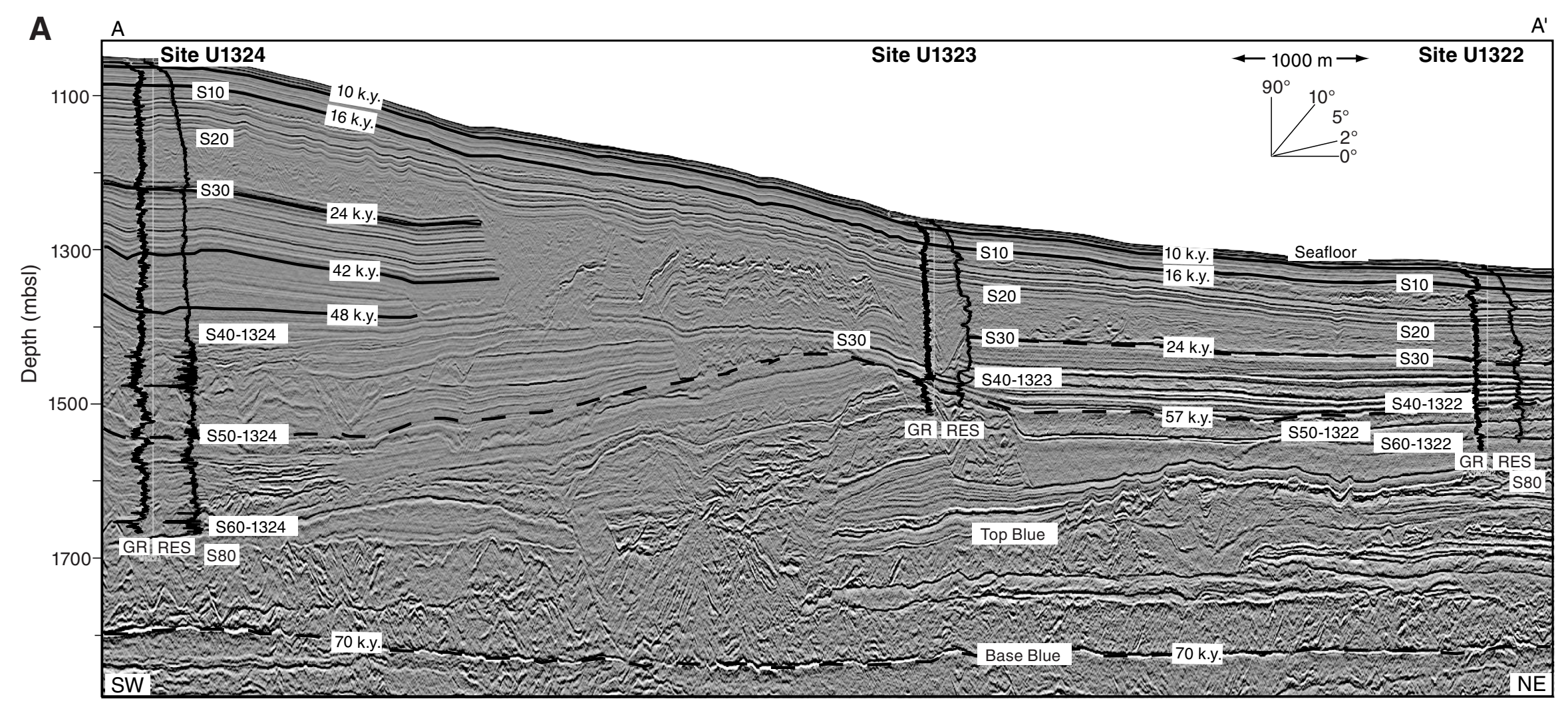


Figure F2 (continued). B. Interpreted well-log cross-section A- $\mathrm{A}^{\prime}$ illustrating the main depositional units and lithology in the Ursa region. Mass transport deposits (MTDs) occur primarily within the thick silty clay levee deposits. Figure from Sawyer et al. (2009).

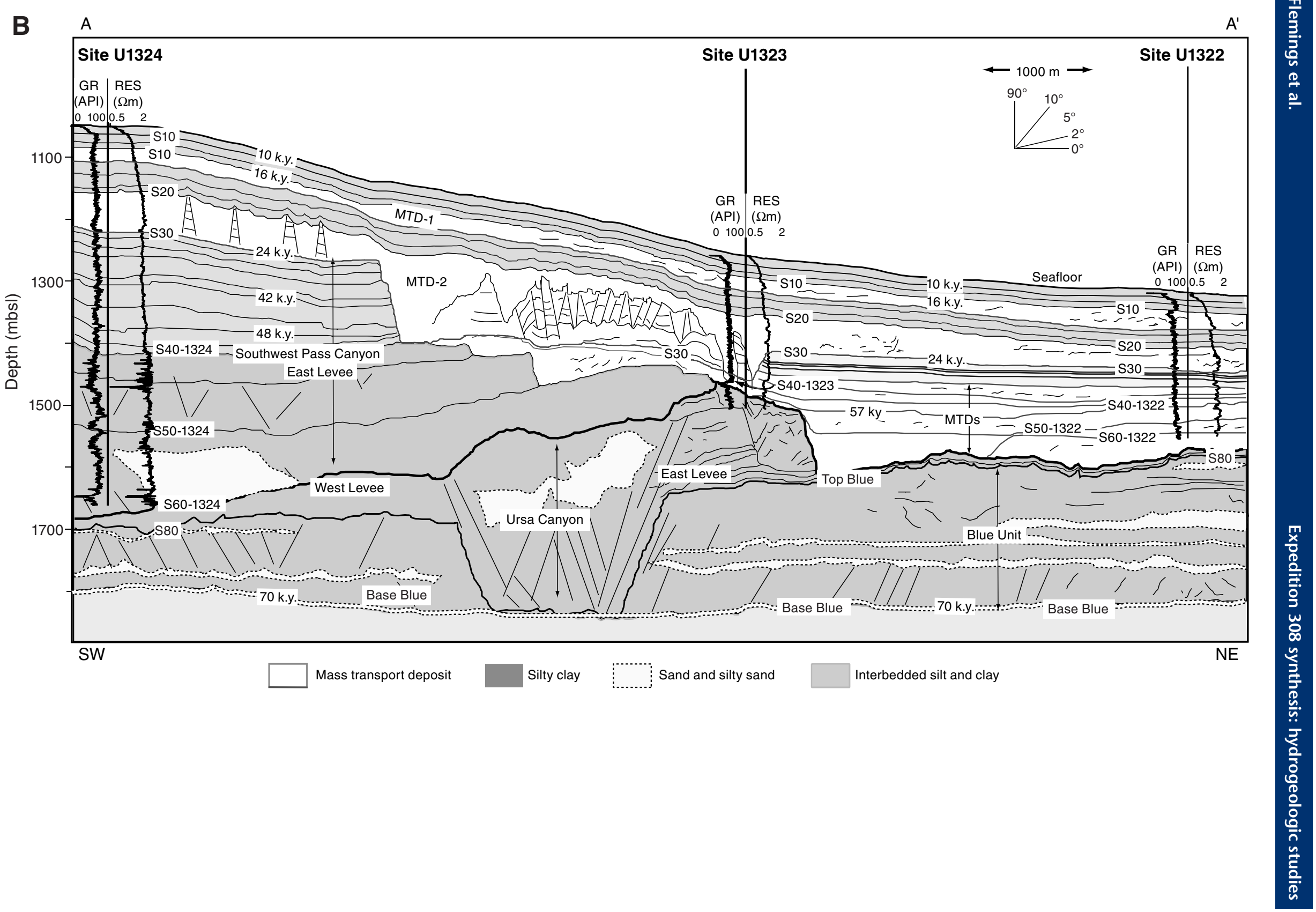


Figure F3. Site U1324 summary (modified from Flemings et al., 2008). A. Lithology. Purple shaded areas are mass transport deposit zones. B. Gamma radiation (GR) from LWD data. C. Resistivity (RES) log. D. Porosity $\log$ interpreted from shipboard moisture and density measurements (squares) and porosity interpreted from LWD bulk density log assuming a grain density of $2.74 \mathrm{~g} / \mathrm{cm}^{3}$ and fluid density of $1.024 \mathrm{~g} / \mathrm{cm}^{3}$ (orange line). E. Overpressure using the inverse square root of time method (Flemings et al., 2008). Pressure measured while drilling (PWD) is shown with solid line. Gray dashed line is the interpreted in situ pressure. Overpressures $\left(u^{*}\right)$ are calculated by subtracting the hydrostatic pressure $\left(u_{\mathrm{h}}\right)$ from the measured pressure $(u) . u_{\mathrm{h}}$ is calculated assuming a pore fluid density $\left(\rho_{\mathrm{w}}\right)$ of $1.024 \mathrm{~g} / \mathrm{cm}^{3}\left(u_{\mathrm{h}}=\rho_{\mathrm{w}} g \mathrm{z}\right) . \sigma_{\mathrm{vh}}{ }^{\prime}$ is the hydrostatic effective stress $\left(\sigma_{\mathrm{vh}}{ }^{\prime}=\sigma_{\mathrm{v}}-u_{\mathrm{h}}\right)$. The overburden stress $\left(\sigma_{v}\right)$ is calculated by integrating shipboard-derived core density measurements. DVTPP $=$ Davis-Villinger Temperature-Pressure Probe, T2P = temperature/dual pressure probe.

\section{Site U1324}

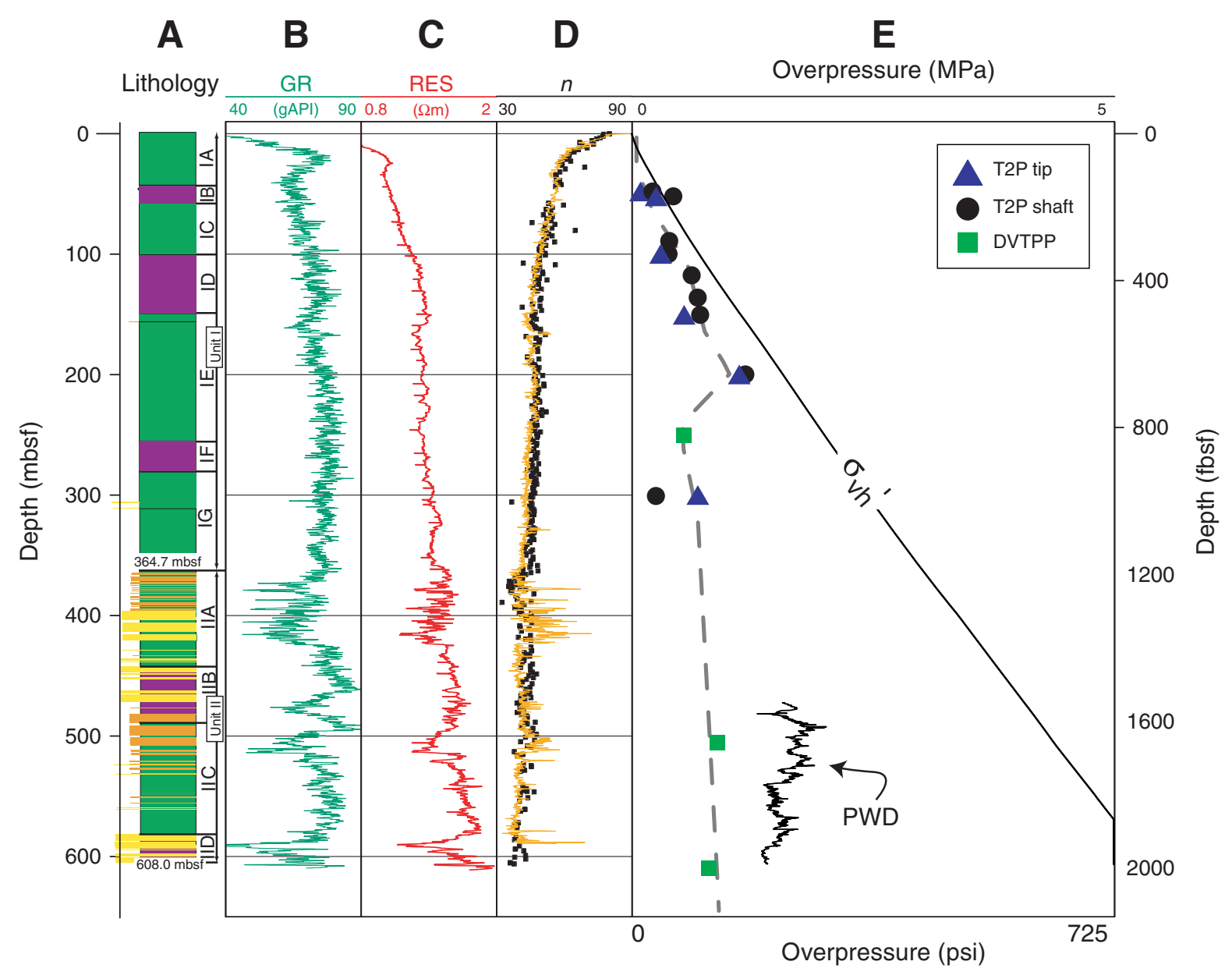


Figure F4. Site U1323 summary. Seismic strip from cross-section A-A' (Fig. F1) with gamma ray and resistivity curves tied to seismic log. Log and core data and description of logging units from Expedition 308 (see the "Expedition 308 summary" chapter [Expedition 308 Scientists, 2006]). Log-derived porosity is based on the bulk density $\log$ assuming $2.74 \mathrm{~g} / \mathrm{cm}^{3}$ grain density and $1.024 \mathrm{~g} / \mathrm{cm}^{3}$ fluid density. Gray shaded zones represent mass transport deposits. Figure from Sawyer et al. (2009).

\section{Site U1323}

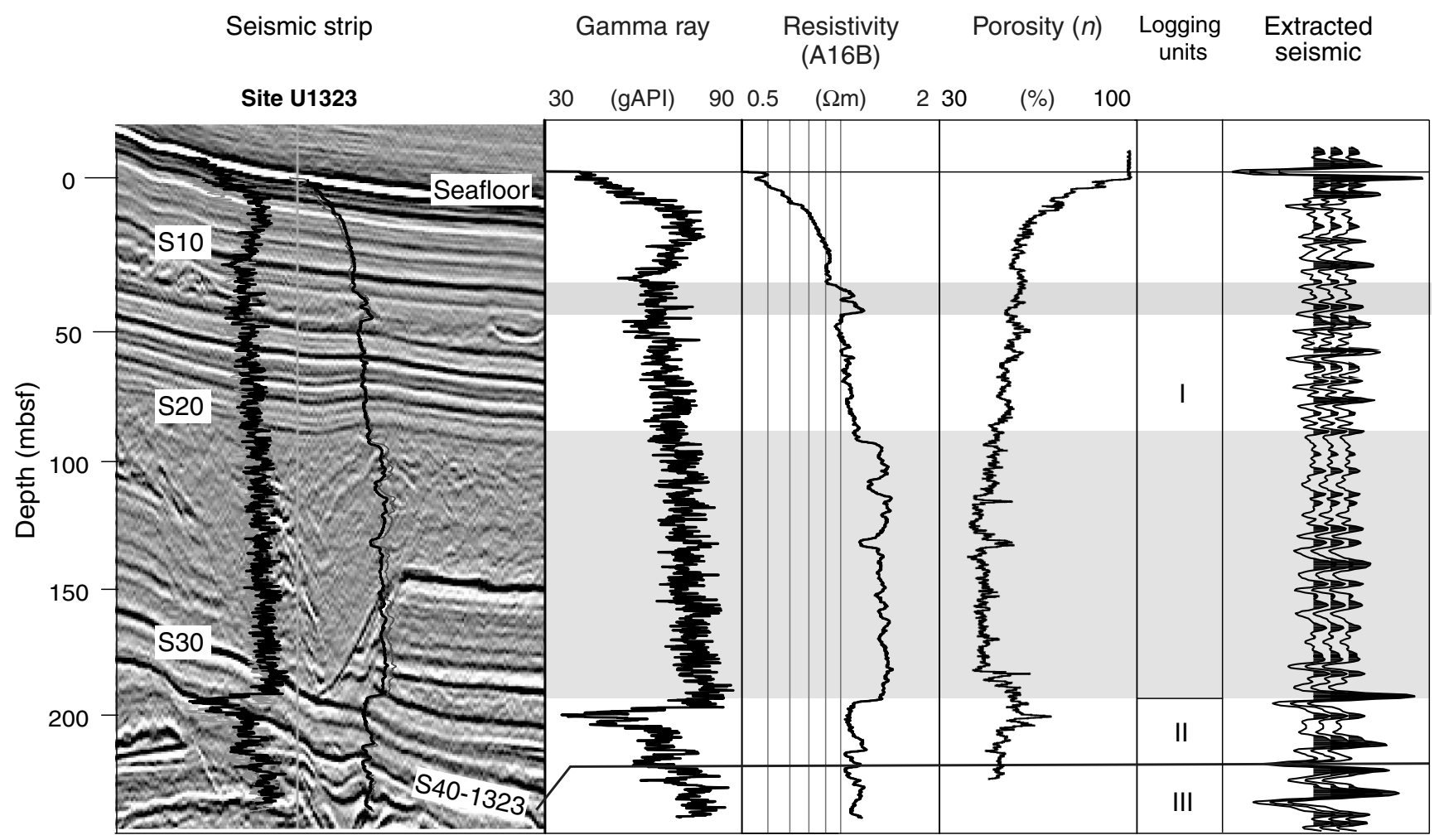


Figure F5. Site U1322 summary. Figure modified from Flemings et al. (2008). A. Lithology. Purple shaded areas are mass transport deposits zones. B. Gamma radiation (GR) from LWD data. C. Resistivity (RES) log. D. Porosity log interpreted from shipboard moisture and density measurements (squares) and porosity interpreted from LWD bulk density log assuming a grain density of $2.74 \mathrm{~g} / \mathrm{cm}^{3}$ and fluid density of $1.024 \mathrm{~g} / \mathrm{cm}^{3}$ (orange line). E. Overpressure using the inverse square root of time method (Table T1). The "?" marks the deepest pressure measurement that has an anomalously low pressure relative to the overlying pressure measurement (see text for a discussion). Pressure during shallow water flow at Site U1323 is illustrated with a star. The grey dashed line is the interpreted in situ pressure. Overpressures $\left(u^{*}\right)$ are calculated by subtracting the hydrostatic pressure $\left(u_{\mathrm{h}}\right)$ from the measured pressure $(u) . u_{\mathrm{h}}$ is calculated assuming a pore fluid density $\left(\rho_{\mathrm{w}}\right)$ of $1.024 \mathrm{~g} / \mathrm{cm}^{3}$ $\left(u_{\mathrm{h}}=\rho_{\mathrm{w}} g \mathrm{z}\right) . \sigma_{\mathrm{vh}}{ }^{\prime}$ is the hydrostatic effective stress $\left(\sigma_{\mathrm{vh}}{ }^{\prime}=\sigma_{\mathrm{v}}-u_{\mathrm{h}}\right)$. The overburden stress $\left(\sigma_{\mathrm{v}}\right)$ is calculated by integrating shipboard-derived core density measurements.

Site U1322

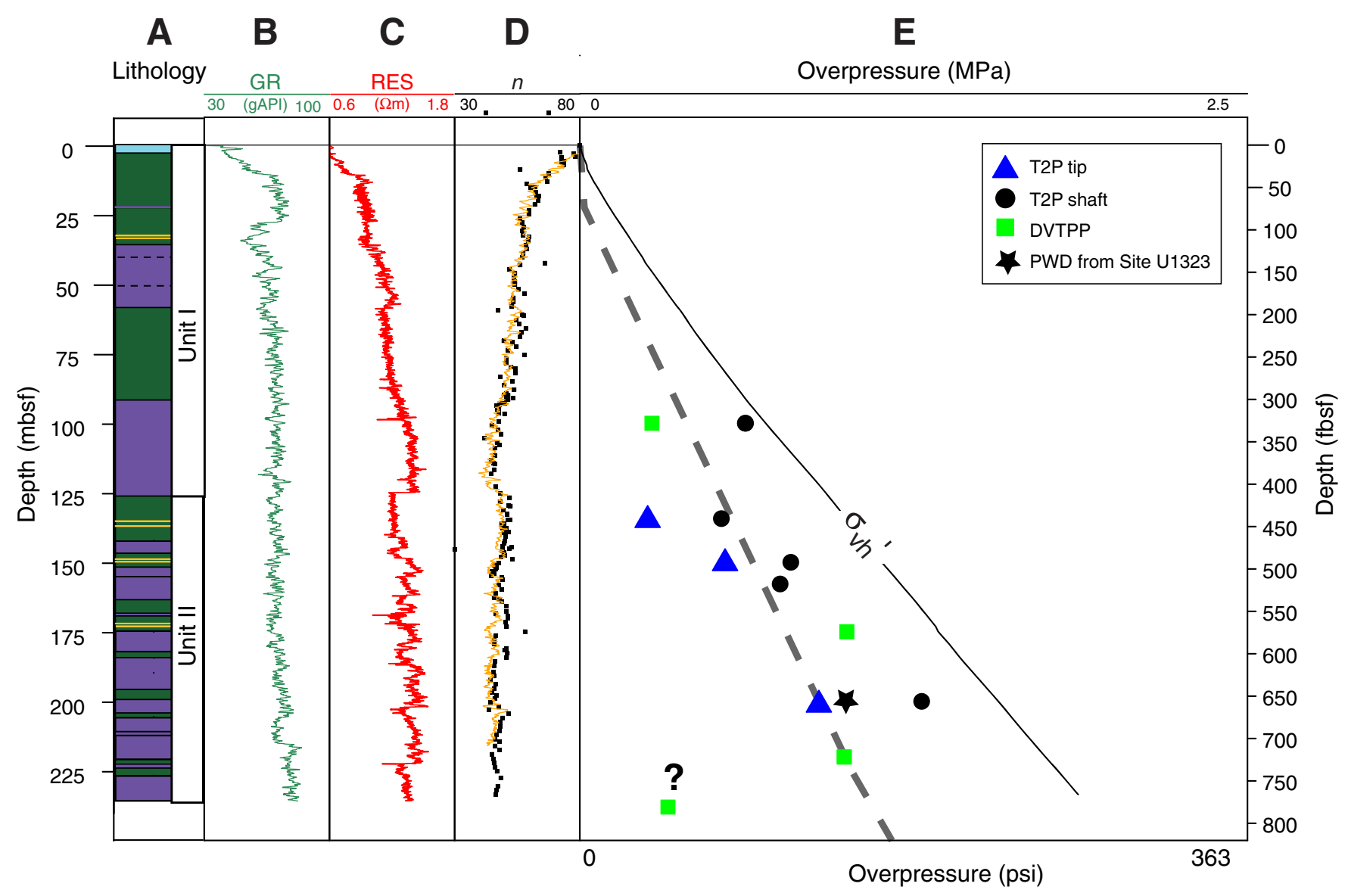


Figure F6. Hydraulic parameters for three characteristic lithofacies encountered in Ursa Basin. MTD = mass transport deposit. A. Porosity vs. effective stress based on experimental results of Long et al. (2008b). B. Permeability ( $k$ ) vs. effective stress based on experimental results of Long et al. (2008b) and Schneider (2011). C. Uniaxial compressibility $\left(m_{\mathrm{v}}\right)$ vs. effective stress based on Long et al. (2011), Long et al. (2008b), and Schneider (2011). D. Coefficient of consolidation $\left(c_{v}\right)$ vs. effective stress. $c_{v}$ is calculated from Equation 3. Equivalent hydrostatic depth (the depth for a pore pressure that is hydrostatic) is for a sediment bulk density of $2.0 \mathrm{~g} / \mathrm{cm}^{3}$ and a water density of $1.023 \mathrm{~g} / \mathrm{cm}^{3}$. A striking feature is that over the depth range of this model (1-100 m hydrostatic depth), the coefficient of consolidation for the mudstone lithofacies is constant and equal to $10^{-8} \mathrm{~m}^{2} / \mathrm{s}$.

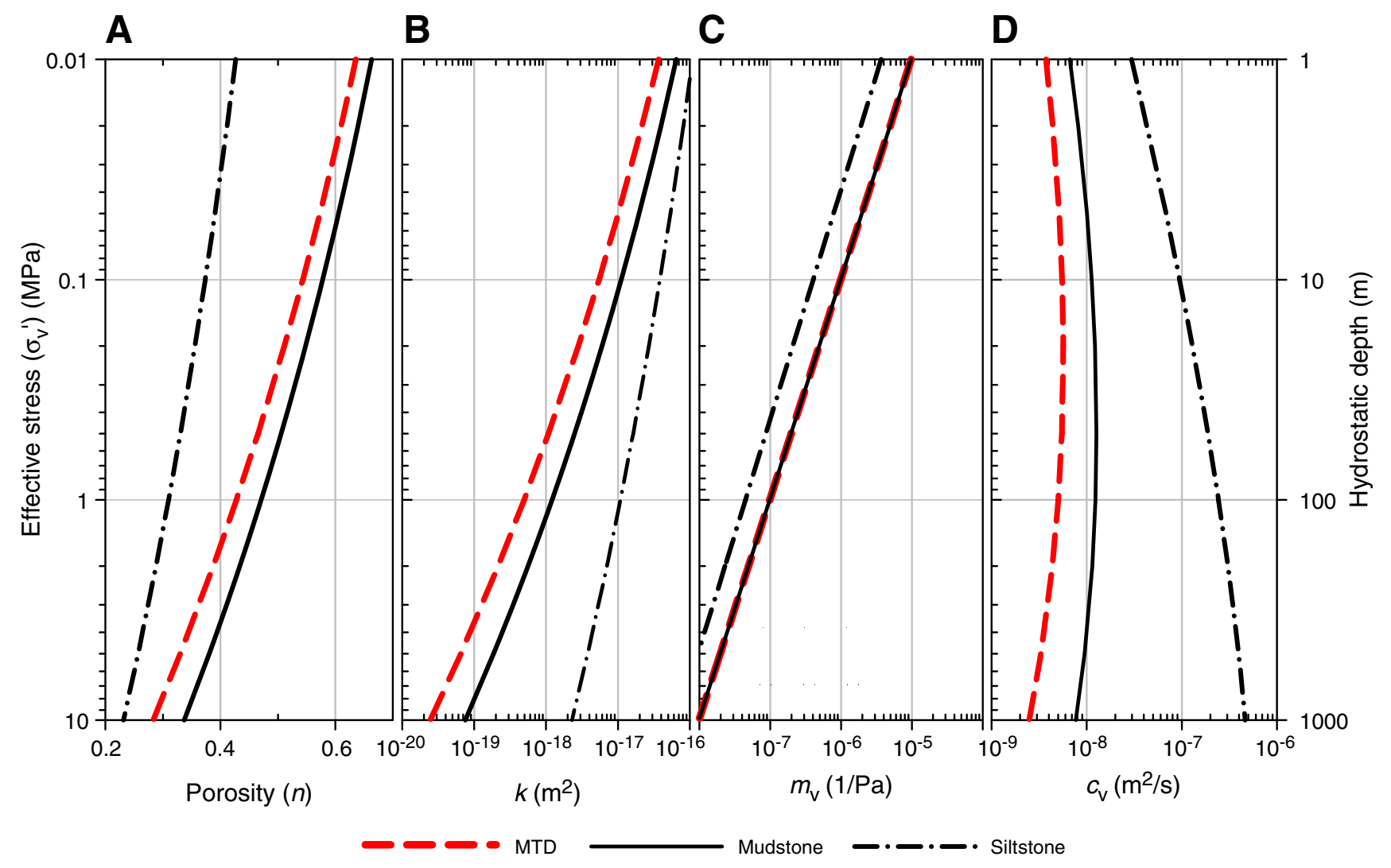


Figure F7. A. 2-D model at present day showing lithologic units and time horizons above the Blue Unit (interbedded yellow and gray layers at base) (Stigall and Dugan, 2010). Dark gray shading represents silty claystone, light gray shading represents clayey siltstone, and yellow shading represents sandstone. B. Color contour plot of overpressure with stratigraphic lines (black) and fluid velocity vectors. Present-day overpressure reaches 1.5 $\mathrm{MPa}$ at Site U1324 and 1.1 MPa at Site U1322. Fluid velocity vectors show focused and rapid flow along the high-permeability sandstones in the Blue Unit from west to east (left to right). Figure and caption from Stigall and Dugan (2010).
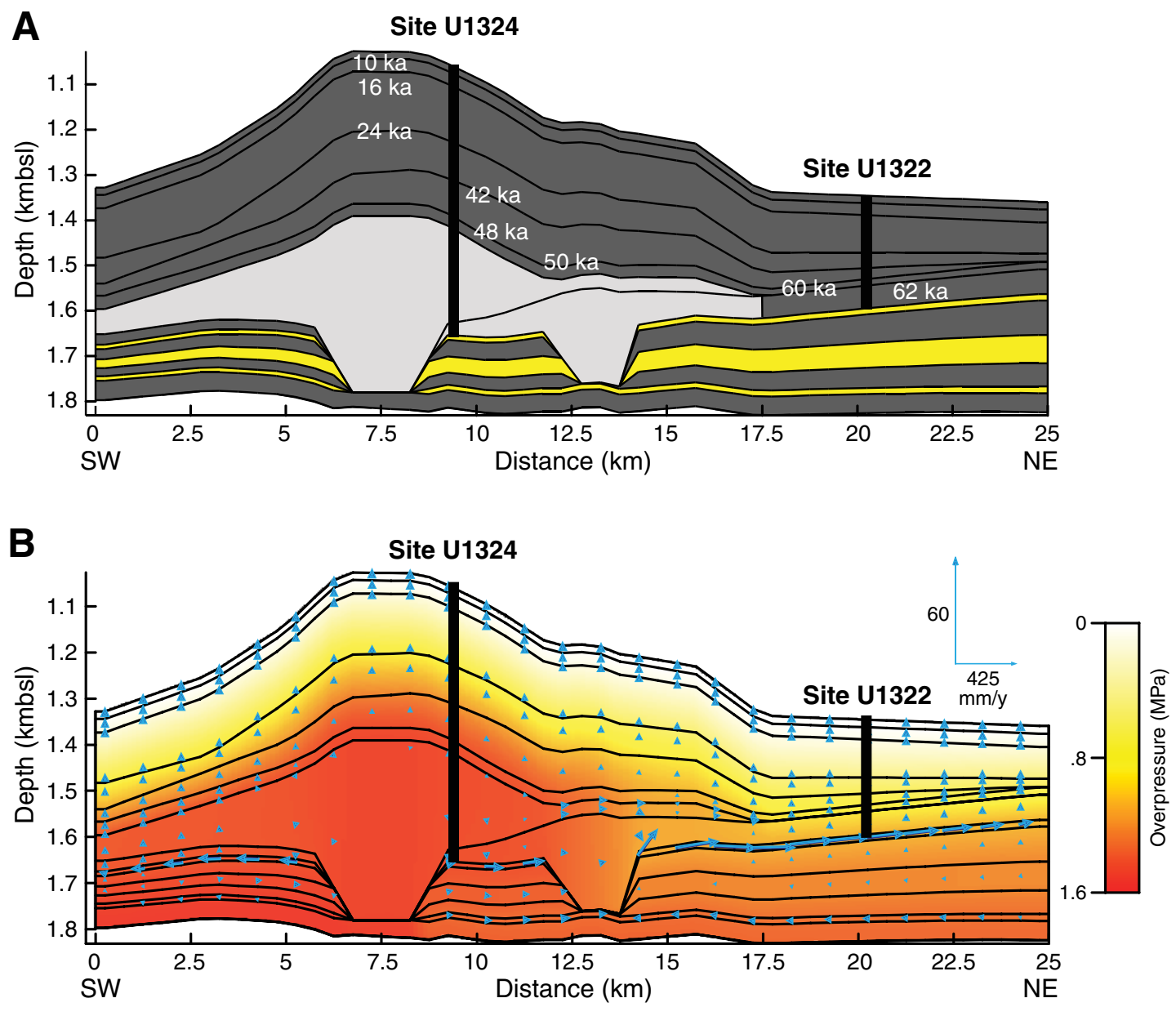
Table T1. Consolidation nomenclature, Expedition 308.

\begin{tabular}{llc}
\hline Variable & \multicolumn{1}{c}{ Description } & Dimension \\
\hline$\gamma$ & Permeability parameter & - \\
$\lambda$ & Compression parameter & - \\
$\lambda^{*}$ & Overpressure ratio & - \\
$\mu$ & Viscosity & $\mathrm{M} / \mathrm{LT}$ \\
$\sigma_{\mathrm{o}}$ & Reference stress & $\mathrm{M} / \mathrm{LT}^{2}$ \\
$\sigma_{\mathrm{v}}$ & Overburden stress & $\mathrm{M} / \mathrm{LT}^{2}$ \\
$\sigma_{\mathrm{vh}}{ }^{\prime}$ & Reduced lithostatic stress & $\mathrm{M} / \mathrm{LT}^{2}$ \\
$\phi_{\mathrm{f}}$ & Friction angle & - \\
$\theta$ & Bathymetric slope & - \\
$C$ & Compression parameter & - \\
$c_{\mathrm{v}}$ & Coefficient of consolidation & $\mathrm{L}^{2} / \mathrm{T}$ \\
$e$ & Void ratio & - \\
$e_{\mathrm{o}}$ & Reference void ratio & - \\
$\mathrm{FS}$ & Factor of safety & - \\
$k$ & Permeability & $\mathrm{L}^{2}$ \\
$k_{\mathrm{o}}$ & Reference permeability & $\mathrm{L}^{2}$ \\
$m_{\mathrm{v}}$ & Compressibility & $\mathrm{LT}^{2} / \mathrm{M}$ \\
$n$ & Porosity & - \\
$t$ & Time & $\mathrm{T}$ \\
$T_{\mathrm{g}}$ & Gibson time factor & - \\
$u$ & Pore pressure & $\mathrm{M} / \mathrm{LT}^{2}$ \\
$u_{\mathrm{h}}$ & Hydrostatic pressure & $\mathrm{M} / \mathrm{LT}^{2}$ \\
$u^{*}$ & Overpressure & $\mathrm{M} / \mathrm{LT}^{2}$ \\
\hline & &
\end{tabular}

Permeability parameter from Equation 5. Compression parameters $\lambda$ from Equation 7 and $C$ from Equation 6 . Reference void ratio from Equations 6 and 7. Reference permeability from Equation 5.

Table T2. Parameters to describe permeability $(k)$ versus porosity $(n)$ behavior for Expedition 308 lithofacies.

\begin{tabular}{lcc}
\hline \multirow{2}{*}{\multicolumn{1}{c}{ Lithofacies }} & \multicolumn{2}{c}{ Equation 5} \\
\cline { 2 - 3 } & $k_{\mathrm{o}}\left(\mathrm{m}^{2}\right)$ & $\gamma$ \\
\hline Mudstone & $10^{-22.48}$ & 9.40 \\
Mass transport deposit & $10^{-22.48}$ & 9.40 \\
Siltstone & $10^{-16.77}$ & 9.19 \\
\hline
\end{tabular}

The parameters for the mudstone and mass transport deposit lithofacies are based on harmonically averaging the results of 29 uniaxial consolidation experiments (see Equation 5).

Table T3. Parameters to describe compression behavior for three Expedition 308 lithofacies.

\begin{tabular}{lccccc}
\hline Lithofacies & $e_{\mathrm{o}}{ }^{*}$ & $C$ & $e_{\mathrm{o}}{ }^{\dagger}$ & $\lambda$ & $\sigma_{0}(\mathrm{MPa})$ \\
\hline Mudstone & 0.89 & -0.0979 & - & - & 1 \\
MTD & 0.75 & -0.0979 & - & - & 1 \\
Siltstone & - & - & 0.4485 & -0.1475 & 1 \\
\hline
\end{tabular}

\footnotetext{
* = void ratio at an effective stress of unity in Equation $6, \uparrow=$ void ratio at an effective stress of unity in Equation 7.
} 